\title{
DIAZEPAM-PENTAZOCINE ANAESTHESIA FOR CARDIOVASCULAR SURGERY
}

\author{
Shigeru Hatano, M.D., PH.D., Donal Keane, M.B., D.A., F.F.A.R.C.S.I., F.F.A.R.C.S.E., \\ Mervin A. Wade, M.D. and MaX S. Sadove, M.D.
}

\section{INTRODUCTION}

IN CARDIOvasCular aNAesthesia in recent years, two techniques, fentanyl and droperidol "Neuroleptanaesthesia," and one using morphine as the primary agent, have shared popularity. ${ }^{1-8}$ Knowledge of the undesirable side effects associated with these techniques, led us to postulate that another tranquillizer-analgesic combination might have some advantages and fewer side-effects.

A review of the pharmacological studies pertaining to analgesics and tranquillizers revealed that pentazocine (dimethylallyl-phenazocine) has minimal cardiovascular depression. ${ }^{9-14}$ Pentazocine is a potent analgesic which is not a narcotic. It was therefore selected as the analgesic for this study. A pilot study was carried out, using pentazocine in a large dose as the analgesic, and droperidol or diazepam as the tranquillizer. A study of 42 surgical cases, ten of which were open heart operations, showed that diazepam was the better of the two tranquillizers.

In this paper, we present an initial series of 320 unselected open-heart operations with cardiopulmonary bypass, anaesthetized by using primarily the combination of diazepam with pentazocine. The data obtained was used as the basis for the evaluation of this combination.

\section{Materials and Methods}

Three hundred and twenty patients were anaesthetized with a combination of diazepam and pentazocine. Two hundred and twenty-nine were males (71.6 per cent) and 91 were female patients (28.4 per cent). They ranged in age from two to seventy-six years and were undergoing operations for various congenital and acquired heart abnormalities. Type of operation and the number of patients are listed in Table I.

The majority of the patients fell within the A.S.A. classification Group III.

Adult premedication, consisting of hydroxyzine $50 \mathrm{mg}$, meperidine $50 \mathrm{mg}$, and atropine sulphate $0.4 \mathrm{mg}$, was given intramuscularly, approximately one hour prior to induction of anaesthesia. Children received meperidine and atropine sulphate in doses appropriate for age, weight, and physical status of the individual child.

Upon arrival in the operating room, pre-induction preparation of the patients consisted of establishment of two intravenous infusion routes, ECG electrodes,

-Department of Anaesthesiology, Rush Presbyterian-St. Luke's Medical Center, Rush Medical College, 1753 West Congress Parkway, Chicago, Illinois 60612. 
HATANO, $e t$ al.: DIAZEPAM-PENTAZOCINE ANAESTHESIA

TABLE I

Type of Surgical Operation

\begin{tabular}{|c|c|c|}
\hline & No. & $\begin{array}{l}\text { Per } \\
\text { cent }\end{array}$ \\
\hline $\begin{array}{l}\text { Coronary Artery Revascularization (C.A.R.) } \\
\text { Valve Replacement } \\
\text { Ventricular Aneurysmectomy } \\
\text { Miscellaneous }\end{array}$ & $\begin{array}{r}156 \\
110 \\
22 \\
21\end{array}$ & $\begin{array}{r}48.8 \\
34.4 \\
6.8 \\
6.6\end{array}$ \\
\hline $\begin{array}{l}\text { B. Congenital Heart Disease } \\
\text { A.S.D. or V.S.D. } \\
\text { Tetralogy of Fallot } \\
\text { Miscellaneous }\end{array}$ & $\begin{array}{l}6 \\
8 \\
4\end{array}$ & $\begin{array}{l}1.8 \\
2.5 \\
1.2\end{array}$ \\
\hline Total & 320 & 100 \\
\hline
\end{tabular}

finger probe for pulse monitoring, blood pressure cuff, rectal and tympanic membrane temperature probes, and Foley urethral catheter. In several cases, the EEG was also monitored and recorded in continuous tracings. A CVP catheter was inserted under local infiltration anaesthesia, and ulnar artery was cannulated for direct blood pressure monitoring.

Induction of anaesthesia in adult patients was accomplished with intravenous diazepam and pentazocine. The dose was calculated on the following basis. Diazepam, $0.4 \mathrm{mg} / \mathrm{kg}$ male patients, $0.3 \mathrm{mg} / \mathrm{kg}$ female patients; pentazocine, $2 \mathrm{mg} / \mathrm{kg}$ male patients, $1.5 \mathrm{mg} / \mathrm{kg}$ female patients. Initially, one-third of the calculated dose of diazepam was given in $5 \mathrm{mg}$ increments. Following this, the pentazocine, diluted to 0.1 per cent $(1 \mathrm{mg} / \mathrm{ml})$ in a solution of 5 per cent dextrose in water, was infused at a rate estimated to give the calculated induction dose over a period of ten to fifteen minutes. During administration of the pentazocine, the patient was hyperoxygenated and denitrogenated with oxygen at a ten-litre per minute flow by mask and the respiratory pattern was observed. After approximately 80 per cent of the induction dose of pentazocine ( 60 to $90 \mathrm{mg}$ ) had been infused, the remainder of the calculated dose of diazepam was given intravenously. With the patient asleep, the trachea was intubated, using $0.8 \mathrm{mg} / \mathrm{kg}$ of succinylcholine chloride as the relaxant.

Induction of paediatric patients was accomplished either by high concentrations of cyclopropane in oxygen, or by an intramuscular injection of ketamine hydrochloride, $5 \mathrm{mg} / \mathrm{kg}$. Succinylcholine chloride, $2 \mathrm{mg} / \mathrm{kg}$, was given intramuscularly and naso-tracheal intubation was performed using a Jackson-Rees nasotracheal tube.

In the first 50 cases oxygen was used alone during induction and maintenance. However, this resulted in administration of excessive doses of pentazocine and diazepam. As a consequence, 50 per cent nitrous oxide was added in the subsequent cases (except during cardiopulmonary bypass). Respiration was controlled by either an Air-Shields or Brompton-Manley respirator. Muscle relaxation was provided by intravenous administration of either d-tubocurarine chloride $(0.3 \mathrm{mg} / \mathrm{kg})$ or pancuronium bromide $(0.05 \mathrm{mg} / \mathrm{kg})$. Maintenance of anaesthesia was accomplished by incremental intravenous administration of diazepam ( $5 \mathrm{mg}$ ) and pentazocine ( 10 to $20 \mathrm{mg}$ ), supplemented with 50 per cent nitrous 
oxide and oxygen. During cardiopulmonary bypass, drugs were administered through the oxygenator as required. Blood gas analysis was done prior to and every 30 minutes during cardiopulmonary bypass. In selected cases impedance cardiograms were taken to determine physiological changes during the induction and to assess stroke volume and cardiac output. In the first 40 unselected cases, naloxone hydrochloride ( 0.4 to $2.0 \mathrm{mg}$ ) was purposely given intravenously at the end of anaesthesia to investigate its antagonistic effects on the respiratory and neurophysiological depression from the large doses of pentazocine.

Upon completion of the operation, the tracheal tube was left in situ and in the cardiac intensive care unit the patient was ventilated by a volume limited ventilator (Mörch's piston ventilator for adults, Engström paediatric unit for children), using moderate hyperventilation. Periodic blood gas analysis as an indicator of acid-base balance and oxygenation was utilized for 6 to 20 hours post-operatively. The tracheal tubc remained in place during this time.

\section{REsults}

Following the initial dose of diazepam and pentazocine, all patients showed good sedation with varying degrees of respiratory depression. However, they were still able to respond to verbal stimuli, taking deep inspirations on command. Administration of the balance of the calculated induction dose of diazepam and pentazocine produced a clinically satisfactory level of light anaesthesia. However, because of the diminished respiratory rate and volume, it was usually necessary to assist the patient's respiration prior to the administration of succinylcholine chloride for tracheal intubation.

Impedance cardiogram studies during induction showed approximately 15 per cent increase in stroke volume and cardiac output, the rate remaining essentially unchanged (Figure 1). There were no significant changes in the ECG pattern. The CVP changes during induction and prior to partial bypass are shown in Table II. Except for the patients with mitral and/or aortic valve disease, the blood pressure and pulse rate tended to increase during induction. Table III shows the percentage of patients displaying changes in blood pressure and pulse rate from induction to establishment of partial bypass.

Thirteen patients receiving $15 \mathrm{mg}$ of d-tubocurarine, and ten patients receiving $4 \mathrm{mg}$ of pancuronium bromide, in a single dose, required a vasopressor for treatment of hypotension after induction. In each case, neosynephrine 0.1 to $0.2 \mathrm{mg}$ was given intravenously with a satisfactory response. Maintenance of anaesthesia was readily accomplished by incremental administration of diazepam and pentazocine, based on clinical assessment of blood pressure, pulse, and pupillary response to surgical stimulation. During cardiopulmonary bypass, nine patients developed hypertension caused by mild hypothermia with its concomitant vasoconstriction. These patients responded to a total dose of 2.5 to $5 \mathrm{mg}$ of chlorpromazine intravenously. From the termination of bypass to the end of the operation further medication was rarely required, anaesthesia being adequately maintained with 50 per cent nitrous oxide and oxygen in the majority of cases. Electroencephalograms showed patterns typical of narcotic-nitrous oxide and oxygen anaesthesia 
HATANO, et al.; DIAZEPAM-PENTAZOCINE ANAESTHESIA
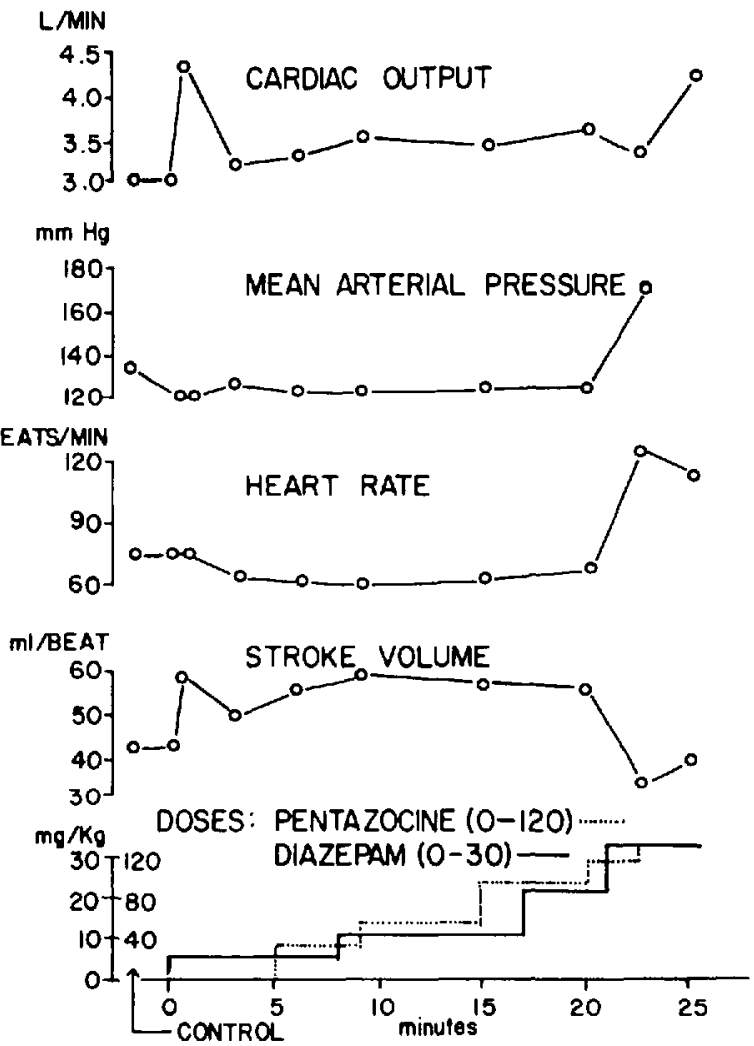

Figure 1. Impedance cardiogram changes during induction ( $N=6$ ).

TABLE II

Average CVP Changes Prior to Bypass

\begin{tabular}{lccc}
\hline \hline Type of Procedures & Number & $\begin{array}{c}\text { Increase } \\
\left(\mathrm{mm} / \mathrm{H}_{2} \mathrm{O}\right)\end{array}$ & $\begin{array}{c}\text { Decrease } \\
\left(\mathrm{mm} / \mathrm{H}_{2} \mathrm{O}\right)\end{array}$ \\
\hline $\begin{array}{l}\text { Coronary Artery } \\
\text { Revascularization } \\
\text { Aortic Valve }\end{array}$ & 156 & $+4.3 \pm 1.9$ & $-5.7 \pm 2.1$ \\
$\begin{array}{l}\text { Replacement } \\
\text { Mitral Valve }\end{array}$ & 57 & $+4.9 \pm 2.0$ & $-7.0 \pm 2.2$ \\
$\begin{array}{l}\text { Replacement } \\
\text { Resection of }\end{array}$ & 36 & $+3.0 \pm 1.1$ & $-9.8 \pm 3.6$ \\
Ventricular Aneurysm & 22 & $+6.0 \pm 2.3$ & $-3.5 \pm 1.2$ \\
\hline
\end{tabular}

throughout the procedure. At no time were convulsive patterns observed. Urinary output was well maintained and potassium chloride 40 to 80 meq was administered during the operation when indicated by electrolyte analysis.

The majority of patients responded to verbal stimulation within a few minutes after discontinuation of the nitrous oxide. Some patients did show varying degrees of respiratory and neurophysiological depression. In the first 40 unselected cases, naloxone hydrochloride was given intravenously. Prompt awakening, with ade- 
TABLE III

Percentage of Patients Showing Blood Pressure Changes (INDUCTION TO BYPASS)

\begin{tabular}{|c|c|c|c|c|c|}
\hline \multirow[b]{2}{*}{$\begin{array}{l}\text { Type of } \\
\text { Operation }\end{array}$} & \multirow[b]{2}{*}{ Number } & \multicolumn{2}{|c|}{ Blood Pressure } & \multicolumn{2}{|c|}{ Pulse Rate } \\
\hline & & $\begin{array}{l}\text { Increased } \\
\text { over } \\
30 \mathrm{~mm} \mathrm{Hg}\end{array}$ & $\begin{array}{l}\text { Decreased } \\
\text { over } \\
30 \mathrm{~mm} \mathrm{Hg}\end{array}$ & $\begin{array}{l}\text { Increased } \\
\text { over } \\
20 / \mathrm{min}\end{array}$ & $\begin{array}{l}\text { Decreased } \\
\text { over } \\
20 / \mathrm{min}\end{array}$ \\
\hline $\begin{array}{l}\text { Coronary Artery } \\
\text { Revascularization }\end{array}$ & 156 & $31.2 \%$ & $14.6 \%$ & $20.8 \%$ & $8.3 \%$ \\
\hline $\begin{array}{l}\text { Aortic Valve } \\
\text { Replacement }\end{array}$ & 57 & 29.6 & 7.6 & 11.1 & 7.4 \\
\hline $\begin{array}{l}\text { Mitral Valve } \\
\text { Replacement }\end{array}$ & 36 & 10.5 & 31.5 & 10.5 & 15.7 \\
\hline $\begin{array}{l}\text { Ventricular } \\
\text { Aneurysmectomy }\end{array}$ & 22 & 25.0 & 18.7 & 31.2 & 0 \\
\hline
\end{tabular}

quate spontaneous respirations, an increase in blood pressure and pulse rate, were observed with the incremental doses of naloxone hydrochloride. However, some of the patients who received naloxone hydrochloride for reversal became restless and strained on their tracheal tubes. Since it is our routine to leave the tracheal tube in place for post-operative respiratory care, restlessness and straining were undesirable. Consequently pentazocine reversal was discontinued for the remainder of the cases unless it was indicated.

Table IV shows the anaesthetic time for the various operations and the average dosage of drugs to maintain an adequate level of anaesthesia. The maximum doses of diazepam, pentazocine, and pancuronium were $65 \mathrm{mg}, 780 \mathrm{mg}$, and 14 $\mathrm{mg}$, respectively.

In the immediate post-operative period, the patients remained calm, responded to verbal instructions, and tolerated their tracheal tubes well. The time of the first dose of post-operative analgesic varied from 1.5 to 19.5 hours, with an average time of 7.45 hours. When required, morphine sulphate ( 3 to $5 \mathrm{mg}$ I.V.) was usually sufficient for the initial postoperative sedation and analgesia. There was total amnesia for the operation in nearly all of the cases. However, three patients definitely recalled the defibrillation procedure. This is a very strong stimulus and has a definite anti-anaesthetic action. Complications encountered during the first seven post-operative days are shown in Table V.

\section{Discussion}

Although morphine and fentanyl have little effect on myocardial contractility, particularly in subjects with cardiac disease, several problems have arisen with these techniques. ${ }^{7,15}$

When one defines anaesthesia as a state of analgesia and unconsciousness, with no increase in neurological reflexes or muscle tone, morphine sulphate in large dosage definitely has effective anaesthesia properties. However, hypotension may occur during induction of morphine anaesthesia, necessitating the administration of fluids, blood and/or vasopressors, especially in patients with intractable heart failure. The prolonged and excessive respiratory and neurological depression 
HATANO, et al.: DIAZEPAM-PENTAZOCINE ANAESTHESIA

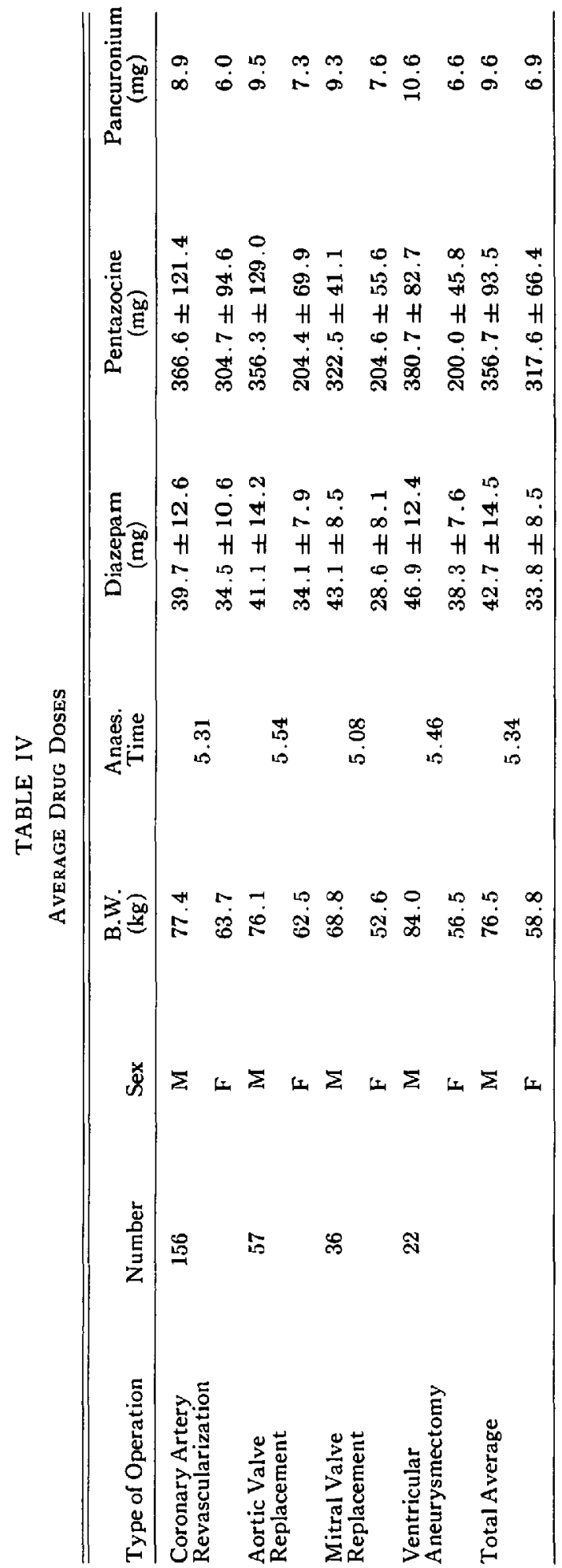


TABLE V

Immediate Postoperative Complications $\left(\mathrm{N}=120^{*}\right.$ )

\begin{tabular}{lll}
\hline \hline Cardiac Arrest & 3 & POD 1 \& 2 Death \\
Ventricular Fibrillation & 4 & POD 1 Resuscitated \\
Dyspnea & 2 & POD 1 Reintubated \\
Respiratory Depression & 4 & POD 1 Reintubated \\
Pulmonary Edema & 1 & POD 1 \\
Pneumonia & 4 & POD 3, 3, 4 \& 5 \\
Laryngitis & 3 & POD 3 to 5 \\
Oliguria & 2 & POD 1 \\
Convulsions & 1 & POD 5 \\
Shivering & 8 & Immed. PO \\
Headache & 2 & POD 1 \\
Drowsiness & 9 & POD 1 \\
Semiconsciousness & 4 & POD 1 to 2, Awake POD 3 \\
Unconsciousness & 1 & POD 1 to 2 \\
Dreams & 6 & \\
\hline
\end{tabular}

* Many patients had multiple minor complications.

†POD-postoperative day.

from morphine, with slow recovery of systemic vascular tone due to direct vascular depression from histamine release, may result in an undesirable postoperative state. As a consequence it may require continuous fluid or blood administration to maintain adequate blood pressure with the possibility of overload and pulmonary oedema. The amnesic properties of morphine are not great and memory of the operation may be a significant complication, especially after defibrillation.

The droperidol-fentanyl combination frequently produces hypotension by the alpha-blocking effect of droperidol. 7,8 Muscle rigidity (thoracospasm or woodychest syndrome), with poor chest compliance and respiratory depression occurs too frequently during rapid induction. The short duration of action of fentanyl necessitates frequent incremental administration of this drug to maintain anaesthesia, while the long action of the droperidol portion may prolong the postanaesthetic recovery period. Occasionally one also sees extrapyramidal symptoms associated with the use of droperidol-fentanyl. ${ }^{7}$ Poor post-operative analgesia and amnesia with early return of pain are also a problem related to this combination.

Diazepam and pentazocine have been widely used in various fields of medicine as tranquillizer and analgesic respectively. However, their application to maintenance of anaesthesia is relatively new. ${ }^{16-20}$ Since 1968, because of stringent narcotic regulations in Japan, pentazocine, in combination with droperidol or other tranquillizers, has gained wide popularity as a supplement to nitrous oxide and oxygen anaesthesia. ${ }^{21-29}$ In 1971, Aldrete ${ }^{30}$ combined pentazocine and diazepam in a fixed ratio of $90 \mathrm{mg}$ and $30 \mathrm{mg}$ respectively. The combination, referred to as "Pentazopam", was added to $250 \mathrm{ml}$ of dextrose-saline solution ( 2.5 per cent and 0.25 per cent) and administered to a series of 200 cases of regional or topical anaesthesia for various operations. In 12 cases the technique was abandoned because of the patients' response to surgical stimulation, indicating inadequate anaesthesia; however, an excellent amnesic effect was provided. In 1972, three papers appeared from different countries ${ }^{29,31,32}$ describing this combination as a supplement to regional or general anaesthesia. These studies concurred on the following points: 
1. The cardiovascular system was essentially unaffected, with minimal fall of blood pressure or change in heart rate.

2. There was a slight decrease in respiratory rate and volume. However, this slight depression was offset by the administration of supplemental oxygen. $\mathrm{PaCO}_{2}$ changes were insignificant.

3. Post-operative residual analgesia and retrograde amnesia were good.

4. The technique was well tolerated by all, including 18 patients with a known history of bronchial asthma.

5. There were no instances of thoracospasm or woody chest syndrome and/or extrapyramidal signs, such as have been reported with the fentanyl-droperidol combination.

The only criticism of any consequence concerned the prolonged sedation, and possible respiratory depression when more than $1 \mathrm{mg} / \mathrm{kg}$ of diazepam was administered. These clinical studies would support the theory that this combination may have positive advantages in comparison to other techniques such as morphine anaesthesia or neuroleptanaesthesia, especially for cardiovascular surgery.

Although pentazocine causes a considerable degree of respiratory depression, similar to other narcotics, ${ }^{33-39}$ it has unique pharmacological action when compared with other potent analgesics. In the average analgesic dosage, pentazocine does not produce cardiovascular depression unless it is given rapidly intravenously. However, the haemodynamic effects of pentazocine in patients with acute cardiac failure are somewhat controversial. In animal experiments, Ahlgren et al. ${ }^{9}$ noted that intravenous administration of $5 \mathrm{mg} / \mathrm{kg}$ pentazocine decreased the systolic blood pressure by an average of 18 per cent while $0.5 \mathrm{mg} / \mathrm{kg}$ of morphine lowered it an average of 25 per cent. This change was transient and returned to control level in less than one minute. Meperidine $(5 \mathrm{mg} / \mathrm{kg}$ ) produced more prolonged decrease in systolic blood pressure ( 75 per cent), which returned to control levels in five minutes. In 1971, Levitsky et al. ${ }^{12}$ and Rifat et al. ${ }^{20}$ reported that pentazocine has a positive inotropic effect. Using a right heart bypass preparation, Levitsky noted that rapid administration of $2.5 \mathrm{mg} / \mathrm{kg}$ pentazocine increased the left ventricular pressure by an average of 28 per cent and demonstrated that force-velocity curves were shifted upwards and to the right, indicating an increase in contractility. Although the inotropic effect was blocked by the prior administration of 0.15 to $0.25 \mathrm{mg} / \mathrm{kg}$ of propranolol, it was not altered in animals depleted of catecholamines by the prior administration of reserpine. This indicates that pentazocine may have a beta-adrenergic receptor stimulating inotropic effect secondary to the release of catecholamines. However, Jewitt et al..$^{40}$ could not find evidence of positive inotropic effect on isolated heart muscle preparations. In a double blind comparison of $48 \mathrm{mg}$ of pentazocine and $8 \mathrm{mg}$ of morphine in stable, pain-free cardiac patients with coronary artery disease, Alderman et $a .^{41}$ found that intravenous morphine administration decreased aortic pressure, cardiac index and venous return which could have contributed to reduction of cardiac output and lowering of the left ventricular end-diastolic pressure. In contrast, marked increase of aortic pressure was observed after pentazocine administration and this was also reported by Scott et al., ${ }^{42}$ as elevation of 
cardiac index. However, Jewitt et al. ${ }^{40}$ observed significantly increased systemic vascular resistance without change in cardiac index. Alderman ${ }^{41}$ also noted that the cause of the elevation of aortic pressure following pentazocine administration was due to increased vascular resistance, rather than increased cardiac output and, overall, it is probably responsible for the elevation of both left ventricular end-diastolic pressure and left ventricular work index. These observations suggest that elevation of myocardial oxygen demand might occur after pentazocine administration and be undesirable for acute cardiac patients.

In contrast, Alderman et al. ${ }^{41}$ commented that "morphine would be considered advantageous from the point of view of diminishing left ventricular work, lowering left ventricular end-diastolic pressure and oxygen demand. However, a reduction in cardiac index and a somewhat variable and unpredictable effect on aortic pressure would be a disadvantage." These previous investigations revealed that cardiac work was decreased by morphine and increased by pentazocine. In 1973, Brogden et al. ${ }^{43}$ reviewed numerous papers related to pentazocine and commented that "the rise in aortic pressure may be of benefit in coronary perfusion, and the absence of a hypotensive effect may be an advantage in cardiac failure patients having hypotension; however, until further work is available, pentazocine should be used with caution in patients with acute myocardial infarction, particularly in those with evidence of left ventricular failure."

From our clinical studies, we concluded that pentazocine tends to increase blood pressure initially in the majority of patients, but hypotension was occasionally observed in patients with mitral and/or aortic valve disease with a fixed cardiac output.

In the pilot study, droperidol and diazepam were tested as the tranquillizer in association with pentazocine. Droperidol-pentazocine, in conjunction with nitrous oxide and oxygen, provided excellent anaesthesia. However, moderate to marked hypotension occurred in a considerable number of the cases during induction. Despite a negative history of any convulsive disorders, one patient developed grand mal convulsions during the induction. A high incidence of convulsions with this combination or with pentazocine alone, was reported by Jackson et al.4 (2 in 21), Isa et al..$^{23}$ ( 2 in 53), Yamamuro et al. ${ }^{45}$ ( 5 in 600), and Suzuki et al. ${ }^{46}$ ( 2 in 55 ). As a consequence, this combination was considered undesirable and was abandoned. Diazepam was substituted for droperidol, in combination with pentazocine.

Diazepam provides smooth induction by selective depression of the limbic system without related cortical depression or hypotension. ${ }^{29,47-49}$ It also produces good muscle relaxation by its combined effects of facilitation of spinal presynaptic inhibition and potentiation of muscle relaxants. The significant anti-convulsive action of diazepam ${ }^{50-62}$ offsets the convulsive effect of pentazocine. Not a single case of convulsions occurred with diazepam-pentazocine combination, and no spike dome or similar seizure pattern was observed on the EEG tracings in our series.

Induction was smooth and hypotension was rarely observed, except after the administration of muscle relaxants as a single dose (i.e. over $15 \mathrm{mg}$ of $\mathrm{d}$-tubocurarine chloride or over $4 \mathrm{mg}$ of pancuronium bromide). Since diazepam 
potentiates muscle relaxants considerably, dosage of the latter should be proportionately reduced and administered slowly to avoid hypotension. The diazepampentazocine combination facilitated maintenance of anaesthesia. The majority of the patients responded to verbal stimulation within a few minutes after discontinuation of the nitrous oxide. Another advantage of this combination is compatability with sympathomimetic drugs when they are indicated.

In order to confirm the experiment of pentazocine reversal by naloxone hydrochloride, previously reported by Kollas and $\mathrm{Smith}^{63}$ and Hatano et al. ${ }^{84}$ an incremental dose of naloxone hydrochloride was purposely given to the initial 40 patients. This resulted in a dramatic reversal of the pentazocine depression. Presumably this is the first clinical confirmation of the antagonistic effects of naloxone for anaesthetic doses of pentazocine, and will be reported at a later date by this department.

Diazepam-pentazocine combination provides excellent residual analgesia and sedation post-operatively. In this series, the average time lapse was 7.45 hours from the termination of anaesthesia to the first administration of an analgesic medication. While pentazocine is known to be a weak narcotic antagonist (1/150 of nalline), it is interesting to note that one patient in this series, a known drug addict, was anaesthetized for coronary artery revascularization without any evidence of withdrawal symptoms. Morphine sulphate was also given intravenously when desired for post-operative pain and provided sufficient analgesia and sedation. This would suggest that the antagonistic effects of pentazocine for potent narcotics are clinically negligible, and compatible with the subsequent use of narcotics such as morphine.

After completion of the initial study of 260 cases, using diazepam-pentazocine anaesthesia for operations with cardiopulmonary bypass, another 60 cases were done using a slight modification of the technique. In these additional cases, the patients received a continuous infusion of 0.1 per cent $(1 \mathrm{mg} / \mathrm{ml})$ pentazocine solution through a micro-mini drip chamber ( $50 \mathrm{drops} / \mathrm{ml}$ ). This modification resulted in a diminution of the total dosage to an average of $295 \mathrm{mg}$ as compared with $356 \mathrm{mg}$ in the initial series, and provided a more consistent level of anaesthesia than incremental administration. While it may not be significant as yet, it was also noted in this latter series that none of the patients were aware of the stimulus of defibrillation. The modified technique is being continued, with the anticipation that further studies will bear out these findings.

\section{Summary}

We have reported a series of 320 patients anaesthetized for operations with cardiopulmonary bypass using a combination of diazepam and pentazocine supplemented with nitrous oxide and oxygen. We found it to be a satisfactory technique for the anaesthetic management of patients with poor cardiac reserve. Ease of induction and maintenance were noteworthy with this technique, with minimal side effects during anaesthesia and in the post-operative period. Although the use of pentazocine in large dosage has not been officially approved, we feel that use of a combination of diazepam and pentazocine in the technique we have 
described has many advantages in anaesthesia for operations with cardiopul. monary bypass.

FoorNore: This study was presented to the Illinois Anesthesiologists Meeting at Champaign, Illinois, November 10, 1973. Since that time, an additional 180 cases have been analyzed. The findings in these additional cases have corroborated those of the initial 320 cases.

\section{RÉSUMÉ}

Nous avons présenté 320 cas de chirurgie à cœur ouvert anesthésiés à l'aide de diazepam, de pentazocine et de protoxyde d'azote. C'est une méthode qui nous a donné satisfaction chez les malades à réserve cardiaque limite. La facilité de l'induction et du maintien de l'anesthésie, le peu d'effets indésirables durant et après l'anesthésie nous ont semblé remarquables avec la technique décrite. Bien que l'usage de la pentazocine à doses élevées n'ait pas encore été approuvé offciellement, c'est notre impression que son usage en combinaison avec le diazepam offre de nombreux avantages pour l'anesthésie des malades subissant une chirurgie à cœur ouvert.

\section{ACKNOWLEDGMENTS}

The authors would like to thank Dr. Hassan Najaf, professor and chairman and the entire staff of the Department of Cardiovascular Surgery, Rush Presbyterian-St. Luke's Medical Center, for their kind assistance in allowing us to carry out these clinical studies.

We would also like to thank Dr. Richard D. Thomason, assistant professor; Mr. Gene Jobgen, laboratory technician and Ms. Gloria Zielin, departmental secretary, of the Department of Anesthesiology for their aid in the preparation of this paper.

$\begin{array}{ll} & \text { GeNeric AND TRADE NAMES OF DRUGS } \\ \text { Fentanyl: Sublimaze } & \text { Ketamine hydrochloride: Ketalar, } \\ \text { Droperidol: Inapsine } & \text { Ketaject } \\ \text { Pentazocine: Talwin } & \text { Succinylcholine chloride: Anectine } \\ \text { Diazepam: Valium } & \text { Pancuronium bromide: Pavulon } \\ \text { Hydroxyzine: Vistaril } & \text { Naloxone hydrochloride: Narcan } \\ \text { Meperidine: Demeral } & \text { Chlorpromazine: Thorazine }\end{array}$

\section{REFERENCES}

1. Lowenstein, E., Hallowell, P., Levine, F., et al. Cardiovascular response to large doses of intravenous morphine in man. New Eng. J. Med. 281: 1389 (1969).

2. Hassrouck, J. Morphine anesthesia for open heart surgery. Ann. Thorac. Surg. 10: 364 (1970).

3. Conahan, T.J. III, Omnisky, A.J., Wollman, H., \& Stroth, R.A. A prospective random comparison of halothane and morphine for open-heart anesthesia. One year experience. Anesthesiology 38: 528 (1973).

4. Conssen, G., Chodoff, P., Domino, E.F., \& Kahn, D.R. Neurolept analgesia and anesthesia for open-heart surgery: pharmacologic rationale and clinical experience. J. Thorac. Cardiovasc. Surg. 49: 901 (1965). 
5. Fox, J.W., Fox, E.G., \& Crandell, D.L. Neuroleptanalgesia for heart and major surgery. Arch. Surg. 94: 102 (1967).

6. Jacobson, E., Nacashmma, H., Shah, N., \& Grank, H.L. Neurolept anesthesia for openheart surgery. A comparative study of 400 patients. Anesthesist, 19: 16 (1970).

7. Grell, F.L., Koons, R.A., \& Denson, J.S. Fentanyl in anesthesia; a report of 500 cases. Anesth. Analg. 49:523 (1970).

8. Dixon, S.H. \& Noran, S.P. Effect of Innovar on myocardial contractility, total peripheral vascular resistance, and capacitance. Anesth. Analg. 49: 331 (1970).

9. Ahlgren, E.W. \& Stephen, C.R. Laboratory and clinical experience with a new analgesic, pentazocine. Anesth. Analg. 45: 673 (1966).

10. Tоммrsto, T., Tokкr, S., \& ToikкA, P. A comparison of the circulatory effect in man of the analgesics fentanyl, pentazocine and pethidine. Brit. J. Anaes. 42: 317 (1970).

11. Keats, A.S. \& Telfond, J. Study of analgesic drugs VIII. A narcotic antagonist without psychotomimetic effects. J. Pharmacol. Exper. Thersp. 143: 157 (1970).

12. Levitsky, S., Mullin, E.M., Sloane, R.E., \& Morrow, A.G. Experimental evaluation of pentazocine; effect on myocardial contractibility and peripheral vascular resistance. Am. Heart J. 81: 381 (1971).

13. Nishrmura, N., Sugmoto, S., Oda, A., Hayashi, F., \& Kamekawa, M. Effect of peutazocine on circulatory system. Japanese J. Anaes, 20:534 (1971).

14. Potter, D.R. \& Rayne, J.P. Newer analgesic with special reference to pentazocine. Brit. J. Anaes. 42: 186 (1970).

15. Stanley, T.H., MaJ, M.C., Gray, N.H., et al. The effects of high-dose morphine on fluid and blood requirement in open-heart operations. Anesthesiology 38: 536 ( 1973).

16. Tommisto, T., Lahdensur, M., \& Fock, G. Peutazocine as a supplement in anesthesia. Ann. Chir. Gyn. Fenniae 56: 319 (1967).

17. Gerula, G.R. \& KeEri-Szanto. Anesthetic time-dose curve VII. Experience with pentazocine. Canad. Anaes. Soc. J. 18: 84 (1971).

18. Brawn, A.S. Pentazocine a potent analgesic: evaluation for anesthesia use. Proc. Royal Soc. Med. 62: 805 (1969).

19. Dobkin, A.B., Israel, J.S., \& Pieloch, P.A. The metabolic response to pentazocine as a supplement to balanced anesthesia for major abdominal surgery. Canad. Anaes. Soc. J. 17: 485 (1970).

20. Rifat, K. Pentazocine in sequential analgesic anaesthesia. Brit. J. Anaes. 44: 175 (1972),

21. Ifatsuki, K., НАsнimoto, Y., Suzki, S., et al. Clinical evaluation of pentazocine, new non-narcotic analgesic. Japanese J. Anaes. 18: 292 (1969).

22. Iwatsuxi, K., Suzuki, S., Yusa, N., NishiokA, K., et al. Modified neuroleptanesthesia with a combination of droperidol and pentazocine. Japanese J. Anes. 18: 1443 (1969).

23. Isa, T., Yamamoto, E., Ozaki, K., KajIWaRA, K., \& Morioka, T. Use of pentazocine for anesthesia. Japanese J. Anes. 19: 1511 (1970).

24. MiYazaki, M. \& FuJITA, T. Clinical study on modified neuroleptanalgesia. Japanese J. Anes. 20: 514 (1971).

25. Mietani, W., Minakuchi, K., \& Nakamura, M. Experience of pentazocine in the field of anesthesia. Shinryo and Shinyaku. 8: 1637 (1971).

26. OKada, $K$. Application of pentagin for anesthesia, its use as neuroleptanalgesia. Pentagin References No. 2 (Sankyo) (1971).

27. Matsuki, A., Kimura, K., Takasawa, T., et al. Clinical study of neuroleptanalgesia in pediatric anesthesia. Japanese J. Anes. 21: 87 (1972).

28. KaKazu, K. \& Shirazawa, S. Clinical evaluation of neuroleptanesthesia for children. Japanese J. Anes. 21: 754 (1972).

29. OGawA, R. \& FUJita, T. Study of neuroleptanesthesia with diazepampeutazocine and $\mathrm{N}_{2} \mathrm{O}$. Shinyaku and Rinsho 21: 25 (1972).

30. Aldrete, J.A., Clapp, H.W., Fishman, J., \& O'Higgins, J.W. "Pentazopam", a supplementary agent. Anesth. Analg. 50: 498 (1971).

31. Jounde, J., Peni, G., Menes, H., \& Menes, R. The value of associating diazapam and pentazocine in an anesthetic contest in maxillo-facial surgery. Ann. Anes. France 13: 173 ( 1972 ).

32. Esser, E., Brisse, B., \& Iserloh, A. Cardiac, circulatory, metabolic and ventilation behavior in jaw surgery using analgo-sedation. DIsh. Azhnarzul. Z. 27: 876 (1972).

33. Hunter, A.R. The respiratory effects of pentazone in rabbits. Anaesthesia 23: 338 (1968).

34. Hunter, A.R. \& Majon, C.T. Pentazocine and niketanide antagonism. J. Pharmacy and Pharmacol. 22: 719 (1971). 
35. Hunter, A.R., Pleuvry, Barbara J., \& Rees, J.M.H. The respiratory depressant effects of barbituates and narcotic analgesics in the unanaesthetized rabbit. Brit. J. Anaes. 40: 927 (1968).

36. Bellville, J.W. \& Green, J. The respiratory and subjective effects of d- and l-pentazocine. Clin. Pharmacol. Therap, 6: 2 (1965).

37. Bellyille, J.W. \& Fonkest, W.H. Respiratory and subjective effects of d- and 1-pentazocine. Clin. Pharmacol. Therap. 9: 142 (1968).

38. Jennett, S., Barker, J.G. \& Forrest, J.B. A double-blind controlled study of the effects on respiration of pentazocine, phenoperidine and morphine in normal man. Brit. $\mathrm{J}$. Anaes. 40: 864 (1968).

39. Davie, I., ScotT, D.B., \& Stephen, G.W. Respiratory effects of pentazocine and pethidine in patients anaesthetized with halothane and oxygen. Brit. J. Anaes. 42: 113 (1970).

40. Jewitt, D.E., Mauner, B.J., Sonnenblick, E.H., \& Shillingford, J.P. Pentazocine: effect on ventricular muscle and haemodynamic changes in ischaemic heart disease. Circulation 44 (suppl. 2):118 (1971).

41. Alderman, E.L., Barry, W.H., Graham, A.F., \& Harrison, D.C. Hemodynamic effects of morphine and pentazocine differ in cardiac patients. New Eng. J. Med. 287: 623 (1972).

42. Scotr, M.E. \& OrR, R. Effects of diamorphine, methadon, morphine and pentazocine in patients with suspected acute myocardial infarction. Lancet 1: 1065 (1969).

43. Brogden, R.H., Speicht, T.M., \& Averu, G.S. Pentazocine: a review of its pharmacological properties, therapeutic efficacy and dependence liability. Drugs 5: 6-91 (1973).

44. Jackson, S.H., Duiker, C., \& Grace, L. Seizures induced by pentazocine. Anesthesiology 35: 91 (1971).

45. Yamamuro, M., Tozawa, T, Otsuka, K., \& Shiozawa, S. Modified neuroleptanesthesia and convulsions. Japanese J. Anes. 21: 578 (1972).

46. Suzuki, T., Yo, K., Matsuura, S., et al. Seizures induced by pentazocine in two pediatric patients. Japanese J. Anes. 21: 1168 (1972).

47. McClish, A. Diazepam as an intravenous induction agent for general anaesthesia. Canad. Anaes. Soc. J. 13: 562 (1966).

48. Dechêne, J.P. Diazepam in pulmonary surgery. Canad. Anaes. Soc. J. 16: 162 (1969).

49. KNapp, R.B. \& Dubow, H. Comparison of diazepam with thiopental as an induction agent in cardiopulmonary disease. Anesth. Analg. 49: 722 (1970).

50. Hernandez-Peon, R., Rojas-Raminez, J.A., O'Flaherty, J.J., et al. An experimental study of the anticonvulsive and relaxant action of valium. Internat. J. Neuropharmacol. 3: 405 ( 1964 ).

51. Eidelberg, E., Neer, H.M., \& Miller, M.K. Anticonvulsant properties of some benzediazepine derivatives. Neurology 15: 223 (1965).

52. Lombnoso, C.T. Treatment of status epileptics with diazepam. Neurology 15: 223 (1965).

53. Swinyard, E.A. \& Castellion, A.W. Anticonvulsant properties of some benzodiazepines. J. Pharmacol. Exp. Therap. 151: 369 (1966).

54. Phensky, A.L., RafF, M.C., Moor, M.J., et al. Intravenous diazepam in the treatment of prolonged seizure activity. New Eng. J. Med. 276: 779 (1967).

55. SawYer, G.T., Webster, D.D., \& SchuT, L.J. Treatment of uncontrolled seizure activity with diazepam. J.A.M.A. 203: 913 (1968).

56. DundeE, J.W. \& Haslett, H.W.K. The benzodiazepines. A review of their action and uses relative to anaesthetic practice. Brit. J. Anaes. 42: 217 (1970).

57. Camerman, A. \& Camerman, N. Diphenylhydantoin and diazepam: molecular structure similarities and steric basis of anticonvulsant activity. Science 168: 1457 (1970).

58. Feinstein, M.B., Lenard, W., \& Mathias, J. The antagonism of local anesthetic induced convulsions by the benzodiazepine derivative diazepam. Arch. International Pharmacolyn. 187: 144 (1970).

59. Sharer, L. \& KUTT, H. Intravenous administration of diazepam: effects on penicillininduced focal seizures in the cat. Arch. Neurol. 24: 169 (1971).

60. Wesseling, H., Bovenhorst, G.H., \& Wiers, J.W. Effects of diazepam and thiopentone on convulsions induced by local anesthetics in mice. Europ. J. Pharmacol. 13: 150 (1971).

61. DE Jong, R.H. \& Heavner, J.E. Diazepam prevents local anesthetic convulsions. Anesthesiology 34: 523 (1971). 
62. DE Jong, R.H. \& HEavner, J.E. Local anesthetic seizure prevention: diazepam versus pentobarbital. Anesthesiology 36: 449 (1972).

63. Kollas, T. \& Smith, T.C. Naloxone reversal of pentazocine induced respiratory depression. J.A.M.A. 204: 932 (1968).

64. Hatano, S., Ide, Y., Moriyama, T., Honda, N., \& Goto, Y. Pentazocine and antagonistic effects of N-Allynoroxymorphone. 7th Annual Meeting of Kyushu Soc. Anes. Beppu, Japan, October 26, 1969. 